УДК 281.96: 94(477.46) «1927»

P.С. Захарченко

\title{
МАЛОВІДОМИЙ УМАНСЬКИЙ ОКРУГОВИЙ СОБОР УАПЦ 1927 РОКУ
}

У статті вперше в історіографіі привертається увага до неактуалізованого досі феномена украӥнського церковно-визвольного руху на Уманщині, зокрема, до існування та діяльності структур УАПЦ в зазначеному регіоні у 1920-ті роки. Одним з виявів організаційної діяльності иієї релігійної спільноти в Уманській та Звенигородській округах Київщини стало проведення Уманського Округового Собору 29-30 серпня 1927 року. Ознайомлення з перебігом цієї невідомої та поважної події регіональної церковної історії нинішньої Західної Черкащини стає можливим завдяки віднайденому та опублікованому протоколузвіту про його проведення.

Ключові слова: Уманський Округовий Собор, Другий Всеукрайнський Православний Церковний Собор УАПЦ 17-30 жовтня 1927 р., Уманщина, Українська Автокефальна Православна Церква, єпископ УАПЦ Костянтин Малюшкевич.

Історіографія регіональної церковної історії західночеркаського регіону за останні кілька десятиліть кількісно виразно збагатилася та стала тематично достатньо розмаїтою. Попри це ще доволі багато не лише питань для порушення, а навіть поважних подієвих пластів та історичних наративів лишаються в локальному історіописанні просто забутими, ба навіть немов зумисно проскрибованими. Надзвичайно дивно і навіть украй болісно визнавати той факт, що у своєму регіональному сегменті історичної пам`яті - i це в умовах Незалежності та відсутності диктату й цензури держави - справжній феномен національної Української Автокефальної Православної Церкви та потужного церковно-визвольного руху на Уманщині у 1920-ті роки й донині не отримав 
анінайменшого зацікавлення. Це, на наш погляд, слід уважати певним відгомоном «специфіки» сучасної релігійної кон’юнктури в регіоні, досі майже безроздільно контрольованому структурами РПЦ.

Відтак те, що визначні місцеві постаті та події національного церковного руху доби НЕПу й на двадцять шостому році Незалежності не отримали не те що суспільного визнання чи пошанівку, а навіть бодай згадування на місцевому рівні, напевно не варто пояснювати самим «банальним» незнанням дослідницьким загалом (радше недостатнім поступом у закритті існуючих «білих плям», дещо консервативними візіями щодо тематичного спектру досліджень церковного минулого Уманщини, обмеженим інтересом до регіональної національної минувшини та - чого гріха таїти - навіть, часом, браком локального патріотизму). Дотеперішнє ж замовчування такого рельєфного історичного наративу напевно слід визнати виразно контрпродуктивним та шкідливим для плекання національно-релігійної свідомості краян. Описана ситуація в регіональній історіографії викликає навіть не щирий жаль, а просто величезний подив та відверте нерозуміння.

У серпні 2017 року минуло дев'яносто років 3 часу проведення в уманському Соборі Св. Олександра малознаної церковно-історичної події Округового Собору УАПЦ (29-30 серпня 1927 року). Такий ювілей є, вочевидь, вартим, аби згадати цей незаслужено забутий епізод церковної історії Уманщини, як і діяльність цього національно-релігійного згромадження в регіоні загалом. Метою нашої публікації є привернення уваги до донині замовчуваного феномена Української Автокефальної Православної Церкви на Уманщині та, зокрема, організаційної діяльності іiі структур на теренах сучасної Західній Черкащині (раніше - Уманській та Звенигородській округах Київщини) у 1920-ті роки. Завданням статті є ознайомлення 3 діяннями та ухвалами Уманського Собору УАПЦ 1927 року за безпосереднім текстом його звіту.

Український автокефальний рух на Західній Черкащині, що поступово визрівав тут ще в 1918-20 pр., почав набирати обертів в регіоні у середині літа 1921 року, коли українізувалася парафія Св. Олександра Невського в Уманю та 
постала Тимчасова православна церковна рада Уманщини - початковий керівний орган, що скоординовував як згаданий рух, так і діяльність українізованих парафій в регіоні [5,арк.1,3,3зв.]. Справжнім початковим промотором цього чину на Уманщині став законовчитель однієї з уманських міських гімназій та голова Уманської учительської спілки о. Костянтин Малюшкевич, котрий незабаром отримав єпископські свячення та був рукоположений на місцевого владику УАПЦ [1,c.642-643].

Про, власне ж, Уманський крайовий Собор УАПЦ 1927 року у відкритих джерелах донині, здається, будь-яка докладна інформація була відсутня - за виключенням хіба що кількох формулярних згадок про факт його проведення у анкетах обраних делегатів від Уманщини та Звенигородщини на тогорічний Другий Всеукраїнський Православний Церковний Собор.

Зокрема, посланцями на останній від регіону тоді були обрані о. Іван Лукашевич з Тального, о. Борис Петренко з Текучої, Дмитро Остапенко з Уманя, Іван Ковтун, о. Тодось Трубій 3 Івангорода, Юрій Поліщук та о. Микола Чижський з Дубової, Михайло Король з Городецького, о. Сергій Горбаренко з с. Христинівки, Митрофан Слободяник з Корабелівки (Карабелівки), о. Северіян Антончик з Бабанки, о. Онуфрій Табачук з Великих Ташликів, о. Юрій Федоренко 3 Війтівки, о. Леонід Мізецький зі Звенигородки, о. Михайло Крижанівський 3 Єрок та катедральний протоєрей Олександр Заячківський $[1, c .458,459,538$ $540,549,550,554,561,571]$. Місцеві делегати виявили себе доволі діяльними в часі проведення Всеукраїнського Православного Церковного Собору у жовтні 1927 року. Зокрема, владика Костянтин головував на багатьох соборних засіданнях, 3 місць подавав свої репліки брат Юрій Поліщук.

На щастя, у фондах Центрального державого архіву вищих органів влади та управління України (ЦДАВО України, м.Київ) під час цілеспрямованого пошуку вдалося виявити, власне, протокол засідання Уманського Округового Собору УАПЦ 29-30 серпня 1927 року, що можна вважати унікальною знахідкою [6]. Вказане джерельне свідчення справді важко переоцінити, оскільки воно проливає світло на багато безпосередніх, дотепер невідомих, обставин та проблемних 
питань внутрішнього життя УАПЦ в регіоні. 3 огляду ж на маловідомість та невідрефлексованість зазначеної події науковим загалом вкрай потрібною видається необхідність оприлюднення цього історичного документа, тому зазначене джерело публікується нами в повному обсязі у додатку. Наведений звіт $\epsilon$ машинописною копією, надісланою до Всеукраїнської Церковної Ради (його було отримано у ВПЦР 3 жовтня 1927 року). Оригінал соборового протоколу, судячи з усього, було втрачено (не виключено, що він пропав під час спалення фондів Уманського державного історичного архіву влітку 1941 року). На початку документа окрім печатки ВПЦР міститься рукописна резолюція про ухвалення Президією цього органу.

Уманський Собор відбувся у обставинах підготовки до Другого собору УАПЦ 17-30 жовтня 1927 р., що мислився його учасниками як «Собор самопізнання» та став вагомою подією в житті цієї Церкви [2; 3; 4,с.232]. Згідно зі «Статутом УАПЦ» Округовий церковний собор мав скликатися Округовою Церковною Радою з відома Всеукраїнської Православної Церковної Ради [1,с. 625]. Згідно з тлумаченням «Наказів церковним соборам і церковним радам УАПЦ», видрукованих щойно напередодні Уманського Собору 1927 року, «Округовий Церковний Собор є вищий керівничий і судовий орган Округової Української Православної Автокефальної Церкви, виявник волі Округової Церкви, як частини всієї Української Православної Автокефальної Церкви» [1,c.493].

Як стає відомо з виявленого текста соборового протоколу, станом на серпень 1927 року на Уманщині та Звенигородщині мережа УАПЦ становила вже достатньо поважну частину православних осередків краю: на той час вже тут нараховувалося 117 українських автокефальних парафій при 111 священиках [6,арк.13в.].

Власне, час початку соборних засідань Уманського Собору УАПЦ у перший день, 29 серпня, на жаль, протоколом не був зафіксований - можемо припустити, що вони розпочалися у Соборі Св. Олександра обідньої пори (не виключено, через отримання того самого дня дозволу на його проведення від адмінвідділу 
Уманського окрвиконкому) - i протривало до 10 години 10 хвилин вечора. Наступного дня, 30 серпня, соборні наради розпочалися із 40-хвилинним запізненням та тривали з 9 годині 10 хвилин ранку до оголошення перерви о 15 годині, наступне засідання тривало з 4:50 до 6:20, і вже надалі по десятихвилинній перерві протривало далі і закінчилося о 21:20. На Собор прибули представники 73 парафій: єпископ, 60 священиків, 3 диякони та 95 мирян. На ньому було розглянуто кілька головних блоків питань: доповідь о. Семена Татарова зі звітом Округової Церковної Ради про стан Церкви в окрузі, їі обговорення та різні фінансові питання, доповіді з місць, доповідь о. Юрія Федорченка про стан УАПЦ iз дискусією щодо неї та вибори членів Округової Церковної Ради й різних підсекцій та установ, підготовка до Другого Всеукраїнського Собору. Власне, обговорення доповіді о. Юрія увиразнило тривожні настрої та очікування уманського духовенства у атмосфері подальшого згущення хмар над Церквою 3 боку большевицької влади, що вимагало пошуку дієвого виходу з кризи.

Публікований соборовий протокол в дійсності потребує ще, поза сумнівом, доволі ретельних розтлумачень і пояснень по кожній згадуваній тут персоні та пункту обговорення - як і подальшого глибшого вивчення. Втім, з огляду на «цілинний» стан даної проблематики такі рефлексії суттєво обтяжили би, власне, дану публікацію, головною метою якої є насамперед інформативне ознайомлення - хоча й запізніле - 3 цим поважним історичним документом 3 національної релігійної історії Західної Черкащини ХХ століття. Чи не головне коло учасників українського церковно-визвольного руху на Уманщині - багато з яких було незабаром репресовано і забуто - таким чином просто вперше стають відомі загалу.

Дозволимо собі наостанок зупинитися лише на ще одному моменті. Так, зокрема, порівняння списків делегатів, що прибули на Другий Всеукраїнський Православний Церковний Собор УАПЦ від Уманської округи, і початково обраних на нього на Крайовому Соборі виявляє істотні розбіжності в складі [6, арк.5] (див. додаток). Це дозволяє припустити, що цей персональний перелік іще зазнав додаткових коригувань (вірогідно, замість осіб, котрі не змогли з певних 
причин поїхати), а також поповнився кількома особами вже після закриття Уманського Собору, вочевидь, узгоджуючись вже у міжчассі до відкриття Собору у Києві 17 жовтня 1927 року. На це, зокрема, вказують мандати делегатів Всеукраїнського Собору, надані Уманською Округовою Церковною Радою (практично усі вони були видані на руки тільки напередодні їхнього від їзду до Києва - 12 жовтня [1,с.538-540,549,550,554,561,571]).

Правопис публікованого документа головним чином збережено (за виключенням виразних хибодруків), абревіатури розкрито, а в деяких місцях за змістом крапки замінено комами, зайві крапки та коми - видалено. Літери та знаки, виділені курсивом, вказують на пізнішу редактуру чорнилом машинописного тексту - здогадно перед відправленням копії для Всеукраїнської Православної Церковної Ради - зроблені найімовірніше рукою о. Л. Поставського. Найпоширеніші скорочення, застосовувані у документі: УАПЦ - Українська Автокефальна Православна Церква, о. - отець, бр. - брат, дияк. - диякон, протод. - протодиякон, ВПЦР - Всеукраїнська Православна Церковна Рада, ОЦР чи ОЦРада - Округова Церковна Рада, РЦР, РЦРада чи Райцерада - Районна Церковна Рада, парцерада - Парафіяльна Церковна Рада. У підсторінкових примітках зазначається оригінальне написання редагованих слів, а також подаються стислі довідки про найпомітніших осіб, що згадуються у джерелі.

\section{ДОКУМЕНТ}

Кінець серпня - вересень 1927 р., Умань. Протокол засідання Уманського Округового Церковного Собору УАПЦ 29-30 серпня 1927 року. Машинописна копія.

Центральний державний архів вищих органів влади та управління України. Ф. 3984. Оп. 3. Спр. 493.5 арк.

\section{К О П І Я}

ПРОТОКОЛ ЗАСІДАННЯ УМАНСЬКОГО ОКРУГОВОГО ЦЕРКОВНОГО СОБОРУ УКРАЇНСЬКОЇ АВТОКЕФАЛЬНОЇ ПРАВОСЛАВНОЇ ЦЕРКВИ, ЩО відбувся 29-30 серпня 1927 р. в помешкані (!) Уманського катедрального Собору 
згідно дозволу Адмінвідділу Уманського Окрвиконкому від 29 Серпня 1927 p. ч[исло] 4/14869.

На Собор прибули представники 73-х парафій в кількости 159 душ в такому складі: 1 єпископ, священників - 60, дияконів - 3, мирян - 95. Почесним головою Собору обрано єп[ископа] Костянтина Малюшкевича. Головою президії Собору обрано о. Леоніда Мізецького ${ }^{1}$, заступниками: - о. Север'яна Антончика ${ }^{2}$ i мирянина - Плахотнюка Микиту Омельковича, секретарями: - о. Гната Цокала i о. Миколу Чижського ${ }^{3}$. До мандатної комісії обрано: о. Онуфрія Табачука ${ }^{4}$, о. Остапа Токаря і бр. Поліщука Юрія Івановича 5 .

Повістка денна:

1) Доповідь про стан УАПЦ. 2) Відчіт О[кругової] Ц[ерковної] Р[ади]. 3) Доповіді $з$ місць. 4) Підготовка до 2-го Всеукраїнського Собору (розгляд і обмірковування програму Собору). 5) Фінансова справа. 6) Вибори членів О[кругової] Ц[ерковної] Р[ади] (ревізкомісії, президії, суду, іспитової комісії, членів В[сеукраїнської] П[равославної] Ц[ерковної] Р[ади] і членів 2-го Всеукраїнського Собору.

По пропозиції в[сечесного] о[тця] Костянтина вносяться зміни, щодо порядку: 1) Відчіт О[кругової] Ц[ерковної] Р[ади]. 2) Доповіді 3 місць. 3) Підготовка до 2-го Всеукраїнського Собору. 4) Доповідь про стан УАПЦ і ріжні вибори. Фінансова справа [долучається] до 1-го пакту (пункту (?) - прим. вид.).

Регламент засідань собору приймається такий: засідання 29 серпня мусить закінчитись о 10 г[одині] веч[ора], 30-го серпня - розпочатись о півдевятої години ранку і закінчитись, коли встигнемо, до 12 [години] дня, а ні - то до вечора 3 відповідними перервами.

\footnotetext{
${ }^{1}$ Мізецький Леонід Викторович, 45 років, протоєрей, настоятель церкви Преображення Господнього м. Звенигородки.

2 Антончик Север'ян Трифонович, 32 роки, священик, настоятель церкви Покрови Пресвятої Богородиці с. Бабанки.

${ }^{3}$ Чижський Микола Іванович, 35 років, священик, настоятель церкви Св. Василія Великого с. Дубової.

4 Табачук Онуфрій Іванович, 42 роки, протоєрей, настоятель храму Св.Св. Косьми та Даміяна с. Великі Ташлики.

546 років, селянин, парафіянин церкви Св. Василія Великого с. Дубової.
} 
1) СЛУХАЛИ доповідь голови ОЦР о. С. Татарова ${ }^{6}$ про життя Уманської церкви (себто УАПЦ на Уманщині - прим. вид.). Доповідач відмічає, що перших три роки існування церкви помічається велике піднесення духа, що доходив до ентузіазму; хутко поширювалась українізація і за цією працею забувалась необхідність внутрішньої організації. Тільки на четвертому році робляться де-які спроби організувати внутрішне життя Уманської церкви. На пятому році Уманська церква, як і вся УАПЦ, переживала надзвичайний мент, коли через помилки керуючих осіб і органів вся церква опинилась в тяжкому стані і була під загрозою смерти. ОЦРада Уманщини, як і инші ОЦРади, перестала існувати, замінившись комісією по унормуванню життя УАПЦ. На протязі шостого року існування починається виправлення попередніх помилок, скликається Округовий Собор, відбуваються Великі Покрівські Збори. 3 цього часу йде організаційна робота в Уманській церкві, скликаються районові собори Уманщини. Районові церкви поставились свідомо до організації Райцерад. Одержавши відповідні інструкції, РЦРади керувались ними. Праця ОЦР тепер виявлялась у виконанні роспоряджень (!) ВПЦР, в об’єднуючій роботі, в керуванні життям парафій. Були де які (!) приємні менти в життю Уманської церкви: відсутність масових зречень священників (!), які помічались в минулі роки; навпаки, було приєднання 2 священників від инших церковних орієнтацій. В минулому році висвячено 10 священників і 2 диякони. В останній час праця О[кругових] Ц[ерковних] Р[ад] полягала в перевірці документів священнодіячів УАПЦ і підготовці до 2 Всеукр[аїнського] Собору. В освітній справі зроблено мало: популярізували (!) необхідність передплати журналу, збирали кошти на школу і т[аке] и[нше]. В книжковій справі зроблена зміна: зроблена книжка, але даються книжки за готівку (кредіт РЦРадам - на 2 місяці). На Уманщині мається 117 парафій, з яких 12 вільних, 111 - священників, 3 яких 6 без парафій. Були випадки порушення церковної дисциплини (!) як з боку парафій, так і з боку священнодіячів. Нарешті доповідачем висловлено побажання, аби Собор ${ }^{7}$ звернув увагу на випадки

\footnotetext{
${ }^{6}$ Татаров (Татарів) Семен Миколайович, 40 років, священик, голова Уманської Округової Церковної Ради, настоятель церкви Покрови Пресвятої Богородиці у с. Городецькому.

${ }^{7}$ У оригіналі - абисобор.
} 
недісциплінованости (!) і дав свої дірективи (!) ОЦР в цій справі. Далі зачитується фінансовий відчіт (!) і акт ревізійної комісії, яка знайшла все записане правдивим.

О. Бережницький запитує відносно авторського гонорару. Відповідає в[сечесний] о[тець] Костянтин, що закон в цій справі говорить про добровільну умову. Тепер ВПЦР підняла хлопотання (!) перед Н[ародним] К[омісаріятом] Ю[стиції] про полегшення (!) в цій справі. В Київі Міська Ц[ерковна] Рада платить сама за всі київські парафії по певній угоді з представником Червоного Хреста.

Запитання про порядок скликання Районових пленумів. Після заслухання думки єпископа, що статут дає нам право на пленуми без особливих дозволів, що так розуміє иุе і ВПЦР, представник Уряду зауважив, що дозвіл треба брати, можно в Окр[уговім] адм[іністративнім] відділі.

О. Бережницький просить, аби зменшити розмір добровільних внесків від парафій. Голова Собору дає пояснення: кошторис О[кругових] Ц[ерковних] Р[ад] передбачає певний внесок від району, а росподіл (!) по парафіям - діло Рай[онної] Це[рковної] Ради.

О. Мізецький висловлюючись відносно перевірки складу священнодіячів, запитує: нащо прийняли 2 священників від інших церков без перевірки. О. Татаров каже, що священників Римаренка і Демяновського прийняли до нас, бо вони на праці виявили свою придатність УАПЦ, як свідчать відповідні РЦР. В[сечесний] о[тець] Костянтин по доповіді ${ }^{8}$ в цілому каже: ${ }^{9}$ загальний напрямок праці ОЦР правдивий, районування пророблено, для перевірки складу священнодіячів зроблено багато, на журнал маємо приблизно 70 передплатників, хто не передплатив, ОЦР розішле; не хватає священників, інформація недостатня, випадків недісципліннованности (!) парафій і священників багато (о. Шелест, о. Карлош і др[угі]). Матер'яльна справа зовсім кепська (від 20\% - до 57\%).

О. Роєцький пропонує відносно недісціплінованних (!) прийняти міри. О. Федорченко $^{10}$ : інформація стояла зовсім слабо, не наладжена справа 3 журналом.

\footnotetext{
${ }^{8}$ Подоповіді.

${ }^{9}$ Крапка 3 комою.

${ }^{10}$ Федорченко Юрій Степанович, 53 роки, священик, настоятель храму Св. влкмуч. Параскеви с. Війтівки.
} 
Єпископ: часом nарафії самі винні, бо не дають точної адреси. Тепер на журнал зроблена знижка і допускається всяка розсрочка.

О. Антончик відмічає, що: 1) в О[кругової] Ц[ерковної] Р[ади] відсутня власна ініціатива, 2) мало звернуто уваги на освітню справу, 3) на виписку журналу, 4) фінансова справа катастрофічна, 5) не було твердої волі для виконання власних ухвал. Потрібно: 1) дати дірективи ${ }^{11}$ на майбутнє, 2) самоудосконалення ОЦР, як керовничого органу $\left.{ }^{12}, 3\right)$ одухотвореня (!) РЦРад, 4) наладити церковну освіту, 5) матеріяльну справу реформувати, 6) організацію саміх парафій перевіряти.

Для редагування резолюцій обірається редколєгія (!) з авторів резолюцій[:] єп[ископа] Костянтина Малюшкевича, свящ. о. Окнянського i свящ. С. Антончика, і таких осіб: о. Лукашевича ${ }^{13}$, о. Пасічника, о. Вишневського, о. Татарова, о. Крижановського ${ }^{14}$.

II.

СЛУХАЛИ доповіді $з$ місць.

1) Уманське $e^{15}$ благовісття (о. Вишневський) - Праця Уманськ[ого] благовісття наладжена, засідання відбуваються, журнал передплачується, був випадок, що райвиконк[ом] не дозволив ремонтувати храму (в с. Городецькому). 2) Христинівське - (о. Велічко) Священники працюють щиро, РЦРада халатна, засідання часто не відбуваються, треба утворити др[угий] центр. 3) Дубівське - (о. Петренко ${ }^{16}$ ) Немає тісного звязку 3 парафіями Підвисоцького р., помічається самоправство голів церковних рад, старост, немає братерської єдности в благовістті. 4) Тальнівське - (о. Суботин) Робота ведеться добре. Трудно тримати звязок з ОЦР, бо РЦРада не має (!) свого кошторису. 5) Катиринопільське (!) - (О. Бережницький) Шкодят (!) нашій справі свящ. Клімов (с. Лисяча Балка), монах в с. Ромейково і свящ. Субчинський (с. Стойково). 6) Лисянське - (о. Цокало) РЦР

\footnotetext{
${ }^{11}$ Дерективі.

12 Керовничогооргану.

13 Лукашевич Іван (Йоан) Іванович, священик, настоятель церкви Пресв. Трійці м. Тального.

${ }^{14}$ Крижановський Михайло Лаврінович, 36 років, священик, настоятель парафії Покрови Пресвятої Богородиці с. Срок.

${ }_{15}$ Уманська.

${ }^{16}$ Петренко Борис Васильович, 28 років, священик, настоятель церкви Св. Йоана Богослова у с. Текучій.
} 
працює нормально. С порушення дисциплини (!) (св. Дігусаров), Боярка переживає кризу. 7) Звенигородське - (о. Мизецький) Благовісник примушенний (!) бути і головою РЦР і секретарем. Священники мандрують по др[угим] парафіям. Обовязки дяків виконують по селах селяне. 8) Іванківське - за два місяці роботи не видно. 9) Теплицьке - (о. Токар) справа гаразд. 10) Гранівське (о. Трубій ${ }^{17}$ ) РЦР працює нормально. Негарно справа 3 хорами по селах. В с. Івангороді зліквідована славянська паралєль. 11) Тернівське - (Голова РЦР) Журнал не всі виписують, бо причет байдужій. Не відвідує РЦР о. Боровицький.

Протод[иякон] Барабан запитує, чому с. Дмитрушки не виконує свого фінансового обовязку перед ОЦРадою. О. Вишневський посилається на параллєль ${ }^{18}($ !) і бідність парафії.

О. Бережницький, на запитання о. Роєцького, дає пояснення, що о. Клімов не рахується в списках священників УАПЦ, свящ. Собчинський не підлягає ухвалам Райцеради. Українізуються: с. Берибіси і с. Росоховатка.

О. Бінецький вносить побажання: 1) Оживити діяльність РЦРади і парцерад, 2) звернути увагу на «двигуна парафії» - священника[,] 3) жити по-братерські.

Мандатна комісія доповідає, що є сумніви відносно правопомічности на Соборі свящ. о. О. Крижанівського, о. Смерчинського, дияк. Тимошенка і 2 мирян с. Кобринової.

Собор ухвалює 2 священникам і 2 мирянам дати мандати, а д[иякон] Тимошенко - гість ${ }^{19}$.

Об'являється перерва о 10 г. 10 хв. веч.

30/VIII Засідання роспочинається о 9 г. 10 хв.

Зачитується заява групи членів Собору про необхідність змінити порядок Собору: перше заслухати доповідь про стан УАПЦ і зразу вибори, а тоді підготовка до 2 Всеукраїнськ[ого] Собору. Прийняли цю зміну.

Заслухали проект резолюції по доповіді голови ОЦРади і доповідям з місць. Заслухавши доповідь голови ОЦРади о. Семена Татарова про життя Уманської

\footnotetext{
${ }^{17}$ Тодось Назарович Трубій, 33 років, священик, настоятель парафії Різдва Пресвятої Богородиці с. Івангорода Уманської округи.

${ }^{18}$ Себто існування в селі також «слов'янської» парафії.

${ }^{19}$ Йдеться про статус присутніх на Соборі.
} 
церкви за 1926/27 рік і працю Уманської Окр[угової] Церк[овної] Ради за той же час, а також фінансовий відчіт за той же час і проект кошторису на майбутній рік. УХВАЛИЛИ: констатувати, що Уманська Окр[угова] Церк[овна] Рада разом 3 єпископом і під його духовним керовництвом давала правдивий напрямок життю Уманської церкви в розумінні дотримуватися принціпів будування УАПЦ і прикладала працю до переведення їх в життя, за що і висловити їй подяку. Відчіт про працю президії, відчіт фінансовий та ревізкомісії прийняти, кошторис на 1927/28 рік ствердити. Рахувати необхідним покриття всіх боргів по членським внескам і книжковій справі до 2 Всеукр[аїнського] Собору. Але Собор не може закрити очей на хиби, що мали місце в роботі ОЦРади: неповне виявлення ініціятиви та власної творчости в праці президії ${ }^{20}$ та окремих осіб-членів ОЦР (в справі освітній, інформаційній, фінансовій і т[аке] и[нше]), відсутність волі, що до (!) виконання власних ухвал; і на майбутнє побажати: самоудосконалення ради, поглиблення розуміння своїх завдань, набуття волі по переведенню в життя своїх постанов і через це піднесення власного авторитету, зокрема: звернути увагу i прикласти всі зусилля до організації парафій, як перших складових одиниць церкви, стежити за діференціяцією (!) i погодженням в праці церковних організацій та осіб, звернути саму пильну увагу на перевірку персонального складу духівництва для всебічного піднесення його, суворо дотримувати норм церковної дисципліни як парафіями так і свящ[енно]-церк[овними] діячами, виявити тих осіб, що порушували іiі, i в разі ${ }^{21}$ потреби, віддати під церковний суд (Шелест[,] Карлаш), порушити справу освіти і керувати нею, популяризувати i поширювати $^{22}$ журнал «Церква й Життя», виявити причини тяжкого матеріального становища і засоб $u^{23}$ усунення їх.

Резолюція приймається всіма при -2 утримавшихся.

Резолюція по доповідям з місць:

Заслухавши доповіді представників РЦРад про місцеве церковне життя ${ }^{24}$

\footnotetext{
${ }^{20}$ Президіi.

${ }^{21}$ Вразі.

22 Іпоширювати.

23 Засобів.

${ }^{24} \mathrm{~B}$ оригіналі тут закінчення речення.
} 
СОБОР УХВАЛИВ: визнати, що Р[айонові] Ц[ерковні] Р[ади] Уманської церкви, що організовані в м[инулому] р[оці], працєю (!) своєю допомогли справі організації Уманської церкви і піднесенню ії життя. Побажати, аби районові церкви після 2 Всеукраїнського Собору скликали свої районові Собори, аб $u^{25}$ нові Р[айонові] Ц[ерковні] Ради, удосконаливши власну працю і життя, подбали про удосконалення організаційного життя парафій і парцерад. По доповідях окремих районів.

УХВАЛИЛИ: 1) по Уманському [району] - порадити Городещькій ${ }^{26}$ парафії звернутись до ОКРадмвідділу для з'ясовання непорозуміння з ремонтом храму.

2) по Христинівському ${ }^{27} \mathrm{p}[$ айону] - побажати, аби районовий центр був перенесен $o^{28}$ в Христинівку, як центр географичний (!). 3) по Дубівському закликати парафії б[увшого] Підвисіцького ${ }^{29}$ р. тісніше зв'язатися з РЦРадою, побратерські ${ }^{30}$ підлягати всім іiі ухвалам, виявляючи в цьому свою свідомість. 4) по Катеринопільському $^{31}$ р. - запропонувати РЦРаді остаточно з'ясувати справу 3 усуненням свящ. Клімова і з служінням свящ. Субчинського. 5) по Гранівському вітати Івангородську парафію, що звільнилась від паралелі (славянської), що перешкоджала іï нормальному життю. 6) по Тернівському р. - закликати через ОЦРаду свящ. Боровіцького до встановлення звязку з РЦРадою.

Резолюція приймається всіма при одному, що втримався. III.

ЗАСЛУХАЛИ ДОПОВІДЬ ПРО СТАН УАПЦ. Доповідач о. Юрій Федорченко. О. [Іван] Лукашевич вносить пропозицію доповідати про стан УАПЦ за останній час 3 - [19]26 р. Пропозиція приймається.

В 1926 р. УАПЦ переживала кризу. В вересні м[инулого 19]26 р. збірається (!) Всеукр[аїнська] нарада по унормуванню життя церкви. Великі Покрівські Збори вивели УАПЦ з ненормального стану: 1) статут зареєстровано, 2) Були

\footnotetext{
25 Або.

${ }^{26}$ Городській.

${ }^{27}$ Христиновському.

${ }^{28}$ Стоїть знак питання.

${ }^{29}$ Підвісіцького.

${ }^{30}$ по братерські.

${ }^{31}$ Катеринопольському.
} 
переведені Округові Собори, 3) видається Журнал, 4) дано принципову згоду на відкриття богословської школи, 5) дан дозвіл на друк книжок.

Тепер зявились знову певні ненормальности в стані зовнішне-правному: представники предсоборної ${ }^{32}$ наради слухали зауваги уряду слідуючого змісту: 1) в розмові з б[увшим] головою ВПЦР В. Потієнком на самоті митрополіт (!) говорив про агонію Радвлади, 2) др[угий] раз митрополіт теж казав, що ${ }^{33}$ влада переживає стан агонії, 3) участь митрополіта в нелєгальному зібрані (!) представників Троєцької парафії (2 чер[вня] б[іжучого] р[оку])[,] 4) лист проф[есора] Шелухина і викреслення з нього митрополитом частини листа, що негативно характеризує ${ }^{34}$ Петлюру, 5) Балачки 3 тихоновцями про взаємний ненапад для боротьби ${ }^{35}$ з обновленнями, яко шпигунами ${ }^{36}$ радянської влади, [котрі] вів митрополіт, а мирянин, член ВПЦР, брав в цьому участь, 6) ВПЦР на все це не реагувала і не інформувала ${ }^{37}$ церкви. Через те Уряд зауважив про це предсоборній нараді для реагування з боку церкви. На цій нараді вирішено було обібрати компетентну комісію, яка б всебічно розглянула справу зовнішнеправного і внутрішнього стану церкви для доповіді на 2 Всеукр[аїнськім] Соборі. До складу комісії входять: Кротевич (головою) і уповноваженні (!) округ, яких обірають на місцях. Митрополіт дав пояснення і до Уряду і до предсоборної комісії, які і зачитуються (див. прот[отокол] предсоборної (!) наради і додатки до нього).

О. Липківський запитує, хто такий єпископ Ромоданів, якого митрополіт називає «руйнатором церкви». О. Петренко «чи бере участь єп. Ромоданів в редколегії». О. Окнянський: «чи персональні, чи принціпові росходження маються між митрополітом (!) і ВЦПР». Єпископ на запитання дає відповідь про голову ВПЦР і про неперсональний характер росходжень. О. Бінецький (!), обговорюючи доповідь, пропонує в резолюцію по доповіді вписати ${ }^{38}$ заувагу про необхідність

\footnotetext{
${ }^{32}$ Представникипредсоборної.

33 Щщо.

${ }^{34}$ Характерезує.

${ }^{35}$ боротьби.

36 шпігунами.

${ }^{37}$ неінформувала.

${ }^{38}$ Впесати (?).
} 
«інтереси церкви поставити вище інтересів персональних». О. Лукашевич: ми шануємо і віримо мітрополітові (!), але він зробив помилки, що шкодливі для церкви. О. Окнянський: кажуть, що помилки можуть бути у всіх, але за них судити не можна. О. Ярославський говорить, що мітрополіта (!) породила церква, що вона ж може його застерігати і $y$ совувати $^{39}$. О. Залевський: ми, як кажуть, перед пропасттю, стан загрозливий ${ }^{40}$, але ми в цьому не поінформовані[,] а чогось ми збіраємось кого-сь (!) судити. О. Пасічник: ми повинні заявити повну лойяльність (!) нашої церкви до влади. Спископ дає спростовання, що $є$ обвинувачення і мітрополіта і ВПЦР, що обовязок церкви реагувати. О. Антончик: наше діло дати відповідь 1) на ті запитання в цій справі, що торкаються нашоі ${ }^{41}$ округи і 2) дати дірективи ${ }^{42}$ на 2 Всеукр[аїнський] Собор в цій справі. О. Федорченко вносить проект своєї резолюції. Спископ: - слід зробити додатки до резолюції о. Федорченка і відмежувати зовнішні терття (!) від внутрішніх і визначити способи ліквідації непорозумінь.

Перерва на 10 хв.

Після перерви зачитується проект резолюції о. Федорченка зредагований тою ж редкомісією, такого змісту:

УМАНСЬКИЙ ОКРУГОВИЙ СОБОР, заслухавши і обміркувавши доповідь свящ. о. Юрія Федорченка про сучасний стан УАПЦ і довідавшись про внутрішні терття між о. мітрополітом і презідією (!) ВПЦР, що привело церкву до тяжкого стану, і про порушення правдивих норм відношення церкви до держави, що поставило ${ }^{43}$ церкву під загрозу позбавлення прав легалізації, визнає внутрішній стан дійсно тяжким і зовнішній загрозливим, а тому

ВИСЛОВЛЮЄ ТАКІ ПОБАЖАННЯ: 1) аби внутрішні тертя були зліквідовані як найскоріше звичайним церковноадміністративним шляхом, 2) аби комісія по обслідуванню стану УАПЦ цілком безсторонне ${ }^{44}$ (!) і всебічно зібрала всі матеріяли для з'ясовання внутрішніх і зовнішніх причин неунормованности

\footnotetext{
${ }^{39}$ Осовувати.

40 Загрозливій.

${ }^{41}$ У оригіналі - «ношої».

42 Дерективи.

${ }^{43}$ У оригіналі «постаыило».

${ }^{44}$ Безсторенне (?).
} 
життя УАПЦ, 3) аби 2 Всеукр[аїнський] Собор вивів УАПЦ із того загрозливого стану, в якому вона перебуває, рахуючись з заувагами Уряду і матеріялами в цій справі комісії і керуючись не інтересами осіб, а церкви в цілому.

Резолюція прийнята при 2 проти.

IV.

ОБРАННЯ ЧЛЕНІВ: (презідії, ревізкомісії, іспитової комісії, суду, членів ВПЦР і членів 2 Всеукр[аїнського] Собору).

Протод. Барабан запитує про якусь опозіцію. О. Залєвській (!) каже, що опозіції, як группи (!), яка руйнує справу, не має (!), а є росходження думок. О. Пасічник: коли є оппозіція (!) нехай подасть свою платформу листівно.

Із наміченних (!) кандідатів в голови ОРЦРади (о. Чижського[,] о. С. Антончика, о. [С.] Татарова, о. Ю. Федорченка, протод. Барабана, о. Ол. Вишневського, о. О. Заячківського ${ }^{45}$, о. Пл. Пахаревського) після їх відмовлення, все ж таки більшісттю ${ }^{46}\left(\right.$ !) голосів при 12 -ти, що втримались головою ${ }^{47}$ президії обрано о. Север'яна Антончика.

О. Семена Татарова в пошану за минулу працю, як голови ОЦРади, обрали почесним членом презідії.

До складу президії обрано таких осіб: о. Леоніда Мізецького, о. Миколу Чижського, о. Олександра Заячківського, о. Л. Поставського, бр. Лук'янчука М. Гр., бр. Остапенка Д[митра] С[авича $]^{48}[$,$] бр. Поліщука Ю[рія] Ів[ановича] та$ кандідатами: Ю[рія] Федорченка та бр. Захаревського А. П.

До ревізійної ${ }^{49}$ комісії обрано: о. І. Лукашевича, о. Г. Цокала, бр. Деркача М., та кандідатом о. О. Табачука.

До церковного суду обіраються: о. О. Токар, о. М. Крижанівський[,] бр. Коробань, та бр. Харченко.

О 3 год. дня робиться перерва і засідання роспочинається (!) о 4-50 хв.

\footnotetext{
45 Заячківський Олександр Васильович, 46 років, протоєрей, настоятель Уманського катедрального собору.

${ }^{46}$ Більшисть.

47 втрималисьголовою.

4858 років, парафіянин Уманського катедрального Собору.

${ }^{49}$ ревезійної.
} 
Ставиться справа виборів членів ВПЦР. Ухвалюється: членами ВПЦР рахувати обраних до президії ОРЦРади і до ревізкомісії:

1) о. Антончика $\left.{ }^{50}, 2\right)$ о. Мізецького $\left.{ }^{51}, 3\right)$ о. Чижського, 4) о. Заячківського, 5) о. Поставського[,] 6) Лук'янчука ${ }^{52}$, 7) бр. Остапенка, 8) бр. Поліщука, 9) о. Лукашевича $\left.^{53}, 10\right)$ о. Цокала, 11) бр. Деркача.

Членами 2 Всеукр[аїнського] Собору Церковного обіраються:

1) бр. Кілимник ${ }^{54}$, 2) о. Горбаренко Сергій ${ }^{55}$, 3) о. Борис Петренко ${ }^{56}[$,$] 4) бр.$ [Микита] Плахотнюк $\left.{ }^{57}, 5\right)$ о. М[ихайло] Крижанівський $\left.{ }^{58}, 6\right)$ бр. [Іван] Ковтунн ${ }^{59}$, 7) бр. Драган $\left.{ }^{60}, 8\right)$ бр. [Митрофан] Слободяник $\left.{ }^{61}, 9\right)$ о. Дмитро Зінькевич ${ }^{62}$, 10) о. Тодос Трубій $\left.{ }^{63}, 11\right)$ о. Онуфрій Табачук $\left.{ }^{64}, 12\right)$ о. Юрий Федорченко ${ }^{65}$, що має бути і членом комісії по обслідуванню стану УАПЦ.

Членом до Малої Ради ВПЦР обрано о. Семена Татарова.

Перерва на 10 хв. О 6 г. 30 хв. [вечора] засідання продовжується.

Поступає пропозіція, аби перерахувати членів Собору.

Мандатна Комісія нарахувала 70 членів.

Всеч[есний] о. Костянтин пропонує рахувати себе правомічними i продовжувати Собор, згідно статуту і церковної практики, але з'огляду (!) на неповну кількість присутніх дальшу частину роботи провести в порядкові інформаційному. Те ж говорять о. Л. Мізецький і о. В. Бінецький.

Пропозіція приймається при 1, що втримався[,] і 3 проти.

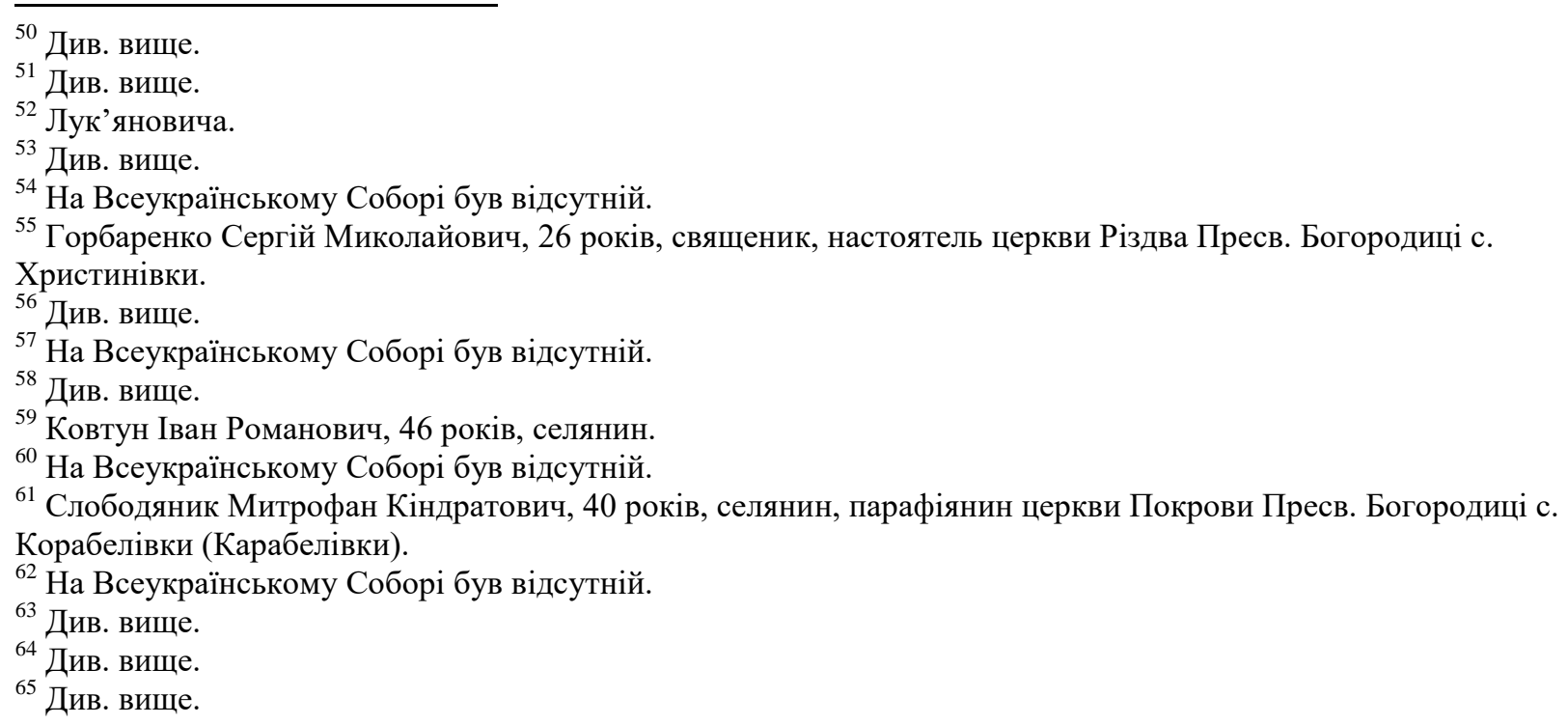


Представник влади вносить свою думку, що він рахує, що Собор не правомічний, але не заперечує продовженню праці.

V.

На оповістці: ПІДГОТОВКА ДО 2 ВСЕУКР[АЇНСЬКОГО] ЦЕРК[ОВНОГО] СОБОРУ.

Всечесний отець Костянтин інформує, що були розіслані відозви, і утворена предсоборна комісія при ОЦРаді. Далі заслухали програм 2 Всеукр[аїнського] Церк[овного] Собору, що до цього прикладається, і коментарії ${ }^{66}$ до нього зроблені єпископом Костянтином, та священником о. Антончиком і свящ. о. Чижським.

СОБОР ВИСЛОВЛЮЕ ТАКІ ПОБАЖАННЯ:

1) аби делегати на Соборі вирішували справи, керуючись інтересами церкви, як підскаже їм власне розуміння і сумління,

2) їхати повинні всі делєгати і не залишати Собору до кінця, о. Антончик відзначає необхідність підготовки парафії до 2 Собору.

Робиться заувага, що делегатам на Собор треба мати документи, треба зараз повідомити ОЦРаду: хто не має кватир в Київі.

Голова Собору виносить подяку всім членам Собору.

Останнє слово дається вс[ечесному] о. Костянтину, в якому він зазначає, що стан УАПЦ тяжкий, що поставитись до нього треба уважно, що необхідно покладати надії на Собор і приготовлятись до прийняття його вирішень, як голосу церкви.

Закінчується Собор молитвою о 9 г. 20 хв.

Почесний Голова Собору

Єпископ Уманський (Костянтин МАЛЮШКЕВИЧ)

Голова Округового Церковного Собору Уманщини

Протоієрей (Л. Мізецький).

Секретарь Священник (М. Чижський).

3 оригіналом згідно:

${ }^{66}$ Комментарії. 
Секретар Уманськ[ої] Окр[угової] Церк[овної] Ради свям[енник] Л. Поставський

\section{ДЖЕРЕЛА ТА ЛІТЕРАТУРА}

1. Другий Всеукраїнський Православний Церковний Собор УАПЦ. 17-30 жовтня 1927 року: документи і матеріали. К.: Інститут історії України, 2007. 698 с.

2. Киридон А.М. «Генеральна репетиція» Другого Всеукраїнського Церковного Собору УАПЦ // Історія релігій в Україні: Наук. щорічник. Кн. 1. Львів: Логос, 2007. C. 479-487.

3. Киридон А.М. Шлях до «Собору самопізнання»: До 80-ї річниці Другого Всеукраїнського Православного Церковного Собору УАПЦ // Проблеми історії України: факти, судження, пошуки: Міжвідомчий зб. наук. праць. Вип. 16: На пошану д.і.н., проф.. С.В. Кульчицького з нагоди 70-річчя від дня народження та 50-річчя наукової праці / Відп. ред. В.А. Смолій: В 2 ч. Ч. 2. К.: Ін-т історії України НАН України, 2007. С. 220-234.

4. Ластовський В. С. «Собор самопізнання» (Другий Всеукраїнський Православний Церковний Собор УАПЦ. 17-30 жовтня 1927 року: документи і матеріали. - К.: Інститут історії України, 2007. 698 с.) // Вісник Черкаського університету. Серія : Історичні науки. 2008. № 133-134. С. 232-233.

5. ЦДАВОВУ. Ф. 3984. Оп. 1. Спр. 155. Листування про приєднання парафій Уманського повіту до Всеукраїнської спілки православних парафій. 1921-24 pp. 56 арк.

6. ЦДАВОВУ. Ф. 3984. Оп. 3. Спр. 493. Протокол засідання Уманського Окружного Церковного Собору (29-30 серпня 1927 р.). 5 арк.

\section{Zakharchenko R.S. Little-known Uman`District Counsil of the Ukrainian}

\section{Autocephalous Orthodox Church (UAPC) in 1927.}

For the fist time in historiography the article focuses on still not updated phenomenon of the Ukrainian church liberation movement in Umanshchyna, in particular it studies the period of time before the Ukrainan Autocephalous Orthodox 
Church (UAPC) started functioning in this region in the 1920s. The District Council which took place on August, 29-30 $0^{\text {th }} 1927$ became one of the signs of the organizational activity of this religious establishment in Uman and Zvenyhorodka districts. The discovery and publishing of the reporting protocol about holding this event makes it possible to learn more about the course of this unknown but very important phenomenon in the regional church history of today`s West Cherkashchyna.

Key words: Uman`District Council (Sobor), The Second All-Ukrainian Orthodox Church Council (Sobor) 17-30 of October 1927, Umanshchyna, Ukrainan Autocephalous Orthodox Church, bishop Kostiantyn Maliushkevych. 